\title{
Correction to: Unexpected tracheal agenesis with prenatal diagnosis of aortic coarctation, lung hyperecogenicity and polyhydramnios: a case report
}

\author{
Alessandro Perri ${ }^{1{ }^{*}}$, Maria Letizia Patti ${ }^{2}$, Annamaria Sbordone ${ }^{2}$, Giovanni Vento ${ }^{2}$ and Rita Luciano ${ }^{1}$
}

Correction to: Ital J Pediatr 46, 96 (2020)

https://doi.org/10.1186/s13052-020-00861-0

The original article [1] contains two errors in Fig. 1:

1) Fig. 1A mistakenly shows a tracheoesophageal fistula instead of the intended image of a tracheal agenesis.

2) There is a small omission in Fig. $1 \mathrm{C}$ whereby arrows intended to annotate the image are missing.

The correct versions of Figs. 1A and $1 \mathrm{C}$ can be viewed ahead in this correction article.

The original article can be found online at https://doi.org/10.1186/s13052020-00861-0

*Correspondence: aleperrix@gmail.com

'Department of Woman and Child Health and Public Health, Child Health Area, Fondazione Policlinico Universitario A. Gemelli, IRCCS, Università Cattolica del Sacro Cuore, Largo A. Gemelli 8, 00168 Rome, Italy Full list of author information is available at the end of the article
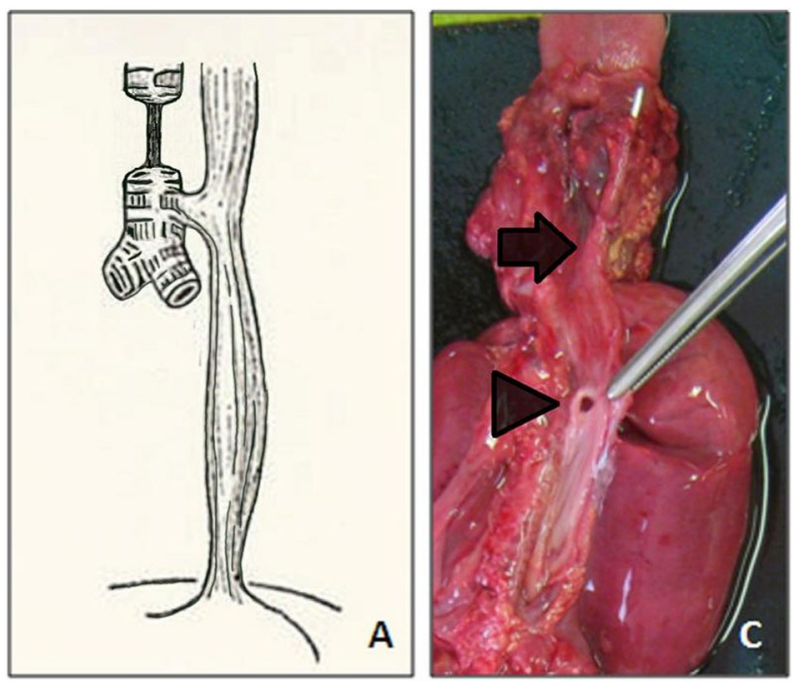

Author details

${ }^{1}$ Department of Woman and Child Health and Public Health, Child Health Area, Fondazione Policlinico Universitario A. Gemelli, IRCCS, Università Cattolica del Sacro Cuore, Largo A. Gemelli 8, 00168 Rome, Italy. ${ }^{2}$ Department of Woman and Child Health and Public Health, Child Health Area, Università Cattolica del Sacro Cuore, Roma, Italy.

Published online: 14 August 2020

\section{Reference}

1. Perri A, et al. Unexpected tracheal agenesis with prenatal diagnosis of aortic coarctation, lung hyperecogenicity and polyhydramnios: a case report. Ital J Pediatr. 2020;46:96 https://doi.org/10.1186/s13052-020-00861-0.

(c) The Author(s). 2020 Open Access This article is licensed under a Creative Commons Attribution 4.0 International License, which permits use, sharing, adaptation, distribution and reproduction in any medium or format, as long as you give appropriate credit to the original author(s) and the source, provide a link to the Creative Commons licence, and indicate if changes were made. The images or other third party material in this article are included in the article's Creative Commons licence, unless indicated otherwise in a credit line to the material. If material is not included in the article's Creative Commons licence and your intended use is not permitted by statutory regulation or exceeds the permitted use, you will need to obtain permission directly from the copyright holder. To view a copy of this licence, visit http://creativecommons.org/licenses/by/4.0/ The Creative Commons Public Domain Dedication waiver (http://creativecommons.org/publicdomain/zero/1.0/) applies to the data made available in this article, unless otherwise stated in a credit line to the data. 